\title{
Project brief: Understanding the lives of adolescents and young adults (UDAYA)
}

Population Council

Follow this and additional works at: https://knowledgecommons.popcouncil.org/departments_sbsr-pgy

Part of the Demography, Population, and Ecology Commons, Family, Life Course, and Society Commons, International Public Health Commons, and the Maternal and Child Health Commons How does access to this work benefit you? Let us know!

\section{Recommended Citation}

"Project brief: Understanding the lives of adolescents and young adults (UDAYA)." New Delhi: Population Council, 2017. 


\section{UNDERSTANDING THE LIVES OF ADOLESCENTS AND YOUNG ADULTS}

(UDAYA)

\section{UDAYA}

The programme "Understanding the lives of adolescents and young adults (UDAYA) in Bihar and Uttar Pradesh" is designed to establish the levels, patterns and trends in the situation of younger (10-14) and older (15-19) adolescents. UDAYA is funded by the Bill and Melinda Gates Foundation and the David and Lucile Packard Foundation. The study is conducted by the Population Council, New Delhi.

\section{UDAYA will}

- EXPLORE the extent to which younger and older adolescents have acquired a set of assets that can help them make a healthy, safe and successful transition from adolescence to young adulthood in the states of Bihar and Uttar Pradesh

- DESCRIBE the extent to which the situation of adolescents has changed over time

- ASSESS factors that determine the accumulation or loss of assets and the quality of transitions from adolescence to young adulthood

As a result, UDAYA provides robust insights on how investments in adolescents influence their life course by the time they reach young adulthood, enables evidence based decisions on the types of programmes worthy of scale-up, and provides important base-line indicators against which the long-term impact of programmes may be measured.

\section{UDAYA's Study design}

The design of this study was guided by a Technical Advisory Committee comprising representatives from the Ministry of Health and Family Welfare, Government of India, non-governmental organisations, and academic institutions.

UDAYA uses both cross-sectional and longitudinal surveys and qualitative studies.

The cross-sectional component involves interviewing independent samples of unmarried girls and boys in ages 10-14 and 15-19, and married girls in ages 15-19 in 2015-16 and 2018-19 in Bihar and Uttar Pradesh. In the first round of cross-sectional surveys, which was done in 2015-16, 10,433 adolescents in Bihar and 10,161 adolescents in Uttar Pradesh were interviewed.

The longitudinal component comprises re-interviewing in 2015-16 the sample of unmarried girls and boys and married girls in ages 15-19 who were first

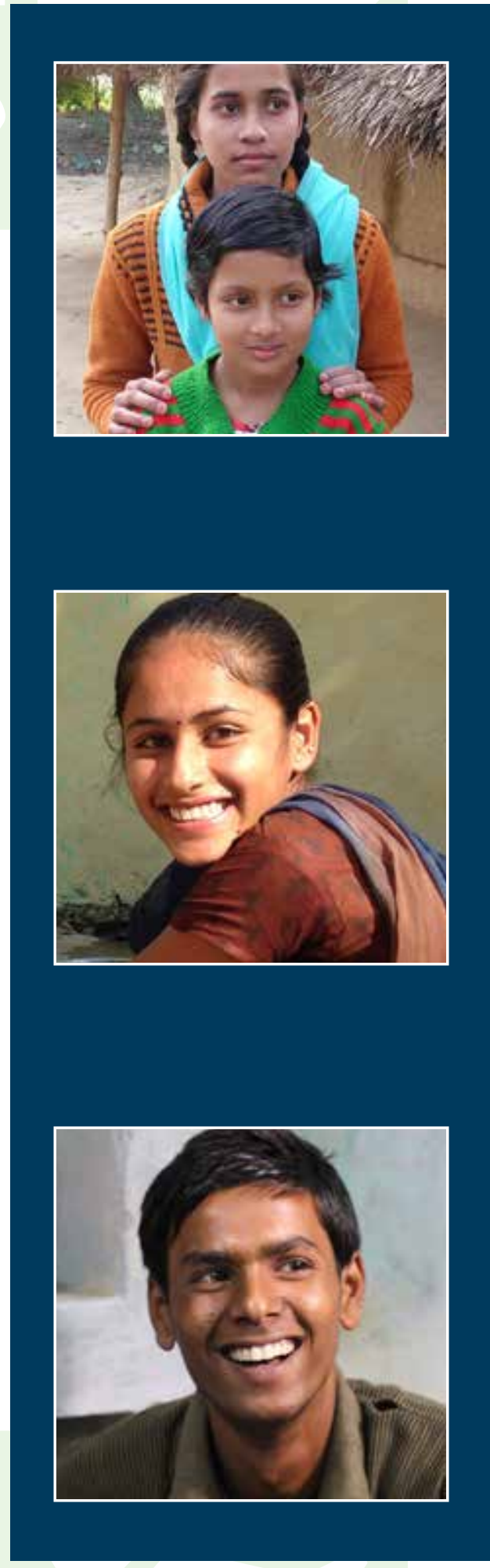


interviewed in 2007 as part of the Youth Study, and were at the time of the re-interview in ages 23-27 in Bihar; and re-interviewing in 2018-19 the sample of adolescents who were interviewed for the first time in 2015-16 in Bihar and Uttar Pradesh.

\section{UDAYA is first-of-its-kind}

Several factors make UDAYA unique:

I. UDAYA provides state-representative evidence on the situation of young adolescents for the first time in two major states of India

II. By using both cross-sectional and longitudinal designs, UDAYA sheds light on changes over time in the situation of adolescents and thereby, on the contributions of recent, increased investments in adolescents in the country and factors that determine successful transitions to adulthood

III. UDAYA profiles the multiple facets of adolescents' lives, including their numeracy and literacy skills, nutritional status and mental health situation

\section{Advantage UDAYA}

In India, the government, bilateral donors and multilateral agencies have supported several social sector programs to improve quality of life of the population and to ensure a healthy, educated, skilled and employed population. Children, adolescents and youth are major beneficiaries of many of these programs.

Absence of longitudinal data, essential to understand the factors that determine, rather than are associated with, healthy transitions from childhood to adolescence to adulthood, and successive cross-sectional data, which are important in establishing the levels of key markers of these transitions at various points in time, have thwarted the designing of optimal programs as well as rigorous assessment of the effectiveness and reach of on-going programs.

UDAYA is a response to these gaps in evidence.

\section{For more information, please visit www.projectudaya.in}

UDAYA data can be accessed at:

https://dataverse.harvard.edu/dataset.xhtml?persistentld=doi:10.7910/DVN/RRXQNT

Follow us on:

https://www.facebook.com/projectudaya/

https://twitter.com/hashtag/projectudaya?src=hash

https://www.youtube.com/channel/UCVQ_XR-CsyYOxOOdP5sqE9g

\section{Population Council}

The Population Council confronts critical health and development issues-from stopping the spread of HIV to improving reproductive health and ensuring that young people lead full and productive lives. Through biomedical, social science, and public health research in 50 countries, we work with our partners to deliver solutions that lead to more effective policies, programs, and technologies that improve lives around the world. Established in 1952 and headquartered in New York, the Council is a nongovernmental, nonprofit organization governed by an international board of trustees.

\section{KEY CONTACTS:}

\section{KG SANTHYA}

kgsanthya@popcouncil.org +91-11-24642901-02

\section{RAJIB ACHARYA}

racharya@popcouncil.org +91-11-24642901-02

\section{SAPNA DESAI}

sdesai@popcouncil.org +91-11-24642901-02 